\title{
Payments for Ecosystem Services: Rife with Problems and Potential-for Transformation towards Sustainability
}

\author{
Kai M. A. Chan ${ }^{a}$, Emily Anderson ${ }^{a}$, Mollie Chapman ${ }^{a}$, Kristjan Jespersen ${ }^{\text {b }}$, Paige Olmsted ${ }^{a}$ \\ a Institute for Resources, Environment \& Sustainability, 2202 Main Mall (4 ${ }^{\text {th }}$ floor), University of \\ British Columbia, Vancouver, B.C., Canada \\ ${ }^{\mathrm{b}}$ Center for Corporate Responsibility, Copenhagen Business School, Denmark
}

\section{Abstract}

Payments for ecosystem services (PES) programs are one prominent strategy to address economic externalities of resource extraction and commodity production, improving both social and ecological outcomes. But do PES and related incentive programs achieve that lofty goal? Along with considerable enthusiasm, PES has faced a wide range of substantial critiques. In this paper, we characterize seven major classes of concerns associated with common PES designs, and use these as inspiration to consider potential avenues for improvements in PES outcomes and uptake. The problems include (1) new externalities, (2) misplacement of rights and responsibilities, (3) crowding out existing motivations, (4) efficiency-equity tradeoffs, (5) monitoring costs, (6) limited applicability, and (7) top-down prescription/alienating agency. As currently practiced, many PES programs are thus of limited benefit and even potentially detrimental to sustainability. From this dire conclusion, we highlight several innovations that might be combined and extended in a novel approach to PES that may address all seven problems. Recognizing that PES necessarily articulate and even normalize values, our proposed approach entails designing these institutions intentionally to articulate rights and responsibilities conducive to sustainability - those we might collectively seek to entrench. Problems remain, and new ones may arise, but the proposed approach may offer a way to reimagine PES as a major social and economic tool for enabling sustainable relationships with nature, conserving and restoring ecosystems and their benefits for people now and in the future.

Extended Keywords: Payments for ecosystem services; reverse auctions; incentive programs; offsets; corporate social responsibility; market-based instruments; motivational crowding out/in; incentives and motivations; stewardship; environmental values; relational values 
Chan et al., Re-Imagining PES

\section{Introduction}

The challenge of sustainability and conserving biodiversity will require solutions that reign in the negative externalities of market transactions. Climate change, habitat degradation and fragmentation, pollution, overharvest, invasive species and disease-all the major threats to biodiversity and ecosystem services (Wilcove, 1998; Millennium Ecosystem Assessment, 2005)—are produced largely via extraction, conversion, transport, and use of goods and services traded in local or global markets.

The existing major tools for environmental policy and management all have encountered obstacles in addressing these pervasive economic drivers. Legislative and regulatory 'command and control' approaches are difficult to implement, in part because those industries that stand to bear focused costs are often highly effective as government lobbyists (Oreskes, 2004), and also because actions must generally be demonstrated harmful before being prohibited. Such evidence of harm is often elusive given that environmental patterns are inevitably cumulative products of diverse drivers of change interacting over multiple spatial and temporal scales (Levin, 1992). Ecosystem-based management (EBM) (Grumbine, 1997; McLeod \& Leslie, 2009) suffers many of the same problems, and it can be costly and difficult to implement given the need for coordination across sectors/agencies, such that EBM as envisioned by experts has been only partly implemented in a few places (Arkema et al., 2006; Chan et al., 2009). Finally, environmental impact assessment, potentially a tool for preventing environmentally damaging development, has more often been a rubber-stamping procedure that approves of all but the most egregious focused impacts (Boyd, 2003; Duinker, 2006; Singh et al., submitted). A fourth kind of solution are environmental incentive programs, including payments for ecosystem services (PES), which involve users of ecosystem services (ES) paying for actions that protect those services (Wunder et al., 2008).

It was PES and similar private finance deals that drove the Economist to declare the 'rescue' of environmentalism (The Economist, 2005), and such business interests continue to promote ES more generally (WRI, 2008). If PES programs could succeed in internalizing the externalities of market transactions, in theory Adam Smith's invisible hand could steer global markets towards sustainability rather than against it. Innovations to economic systems have tremendous potential for positive change and are absolutely essential for sustainability (Daily \& Ellison, 2002; Helm, 2015; Chan et al., in press).

However, although PES programs were initially met with considerable hope, they have also been fraught with controversy, which appears to have thwarted their expansion. One outright rejection is associated with the commodification of nature, and the concern with any market-based rationale to protect ecosystems when it is the same market-based motivations that fuel the consumption that drives environmental degradation (Kosoy \& Corbera, 2010; McAfee \& Shapiro, 2010; Spash, 2008). Proponents as well as detractors within the ongoing commodification debate have become more sensitized as well as cautious concerning the capacity, scope and overall ambition for PES initiatives worldwide (Prudham, 2007; Gómez-Baggethun \& Ruiz-Pérez, 2011; Gómez-Baggethun \& Muradian, 2015). This is particularly evident in discussions around the ethical implications and social consequences of introducing incentive programs into a community setting (Brooks et al., 2012; Luck et al., 2012; McAfee \& Shapiro, 2010; Norgaard, 2010). Despite such concerns, PES programs continue to garner substantial interest worldwide, despite large-scale institutional failures of similar market instruments, such as the inability to establish an internationally recognized and supported carbon 
market (Dixon \& Challies, 2015).

In this article, we address those practitioners and scholars who see some value in incentive-based approaches to ecological problems but who may see shortcomings in their current contribution to a more sustainable world. We take a somewhat unusual stance of pairing a diversity of fundamental critiques with constructive proposals, assessing incentive programs and their potential contributions to sustainability-realized or not-from multiple perspectives. Specifically we bring to bear expertise in environmental values, cultural ecosystem services, social-ecological systems and corporate social responsibility; we also incorporate insights from sociology, social psychology, and anthropology. Most writing on PES implicitly either accepts or rebukes the fundamental premises of economic efficiency and monetary incentives as helpful towards sustainability, with PES proponents proposing design changes to address particular flaws in PES programs as economic tools (e.g., Jack et al. 2008; Engle 2016; Rode et al. 2015). Others have offered important guidance for selecting among a broader set of economic tools, in recognition of the limitations of PES (e.g., Lockie 2013; Rode et al. 2016), given existing understandings of rights and responsibilities. These are important contributions.

This article takes a step back, explicitly considering the legitimacy and applicability of critiques while acknowledging the merits of the overall process of incentivizing conservation and restoration. After briefly defining the scope of incentive programs considered, we characterize seven major sets of objections/critiques that have been levied at PES in a range of relevant literatures. We then consider how several major design changes could lead to a novel redesign of PES as social and economic tools, responding to emerging understandings of environmental values (e.g., Chan et al., 2016). In particular, we engage explicitly with PES as institutions that articulate and affect responsibilitiespotentially intentionally extending responsibilities beyond existing understandings. We draw from existing approaches within and beyond PES to recommend a suite of conceptual shifts and corresponding practical approaches to address each of the seven critiques-and to extend stewardship responsibilities broadly in producer communities and across supply chains. We propose that this approach might simultaneously address important challenges to PES and help the ES concept live up to its highly touted potential.

\section{PES, A Brief Introduction}

In this article, we address a broad basket of incentive-driven programs and projects intended to protect or provide sustainable flows of ecosystem services, commonly referred to as PES (Wunder, 2005, 2013; Muradian et al., 2010; Barrett et al., 2013), but also including a variety of related programs (e.g., what Swallow et al. (2009) termed compensation and rewards for environmental services). PES can refer to small local projects targeting specific species, such as the Wildlife Conservation Society's program that sold hunting permits for a rare turkey in Guatemala to fund conservation of its habitat. They may also be substantially larger in both geographic and monetary scale, such as Norway Environment Ministry's \$1 Billion USD investment to the Brazil Amazon Fund to fund programs encouraging afforestation and reducing deforestation. PES programs can be private arrangements, government driven, or some hybrid of the two. In Ecuador and elsewhere, water funds are collaborations between municipal governments, environmental NGOs, private firms and local water users. In these arrangements beneficiaries of clean water pay into a trust that funds watershed restoration projects to enhance the quality and quantity of urban water delivery (Goldman et al., 2008).

PES have captured rapidly expanding attention. For instance, there were 13 articles in Google scholar 
with the term "payments for ecosystem services" before 2000, 182 between 2001 and 2006, and 6830 between 2007 and 2015. This literature reveals mixed results with respect to endorsement of PES, where synthesis is hampered by a lack of established metrics for success (Daniels et al., 2010; Dougill et al., 2012; Prager et al., 2015). Learning across contexts has been challenging due to the wide range of sectors, sizes and types of projects (see Brouwer et al., 2011; Engel et al., 2008). In short, the promise of PES remains largely unproven (Kinzig et al., 2011; Naeem et al., 2015). And yet optimism remains, from large funders and long-term government programs, and implementation continues.

The expanding literature on PES has important gaps. The vast diversity of projects (based on services targeted, spatial and temporal scales, kinds of participants, landscape types, and contractual arrangements) makes it difficult to discuss PES as a unit, and yet many papers do just this. Broadbrush arguments can impede progress, because appropriateness of program designs depends on various dimensions of context (Wunder et al., 2008; Corbera et al., 2009; Kemkes et al., 2010; Brooks et al., 2012; Muradian et al., 2013).

Several recent reviews have begun to address this gap by identifying important conditions and contexts and which design features of PES are most appropriate for each (Jack et al., 2008; Lockie, 2013; Samii et al., 2014; Engel, 2016). In addition to these 'best practice' suggestions, ideas have been put forth to improve our conceptualization of PES (e.g. Swallow et al. 2009). However, a substantial gap remains between these constructive suggestions for improving PES programs and the more fundamental critiques that have been levied against PES and market-based mechanisms more generally (Kosoy \& Corbera, 2010; McAfee \& Shapiro, 2010; Spash, 2008). The following seven critiques-ordered for flow of ideas and not for importance-draw from and synthesize both the critical and constructive literature on PES. While not an exhaustive set, we hope they constitute an important starting point to advance cross-disciplinary conversations.

\section{Seven Problems}

\section{New Externalities, "A cure for every ill, an ill for every cure"}

The danger with any new market or system of incentives intended to address environmental externalities is that it will itself yield actions with unintended consequences in the form of new externalities. This is essentially a case of Goodhart's Law, which states that once an indicator is made a metric for success, it will cease to function as an effective metric because individuals and firms will find and exploit loopholes that enable success by the metric without its intent (Newton, 2011). Several authors have pointed to this general danger in the context of PES, as participants pursue funding from the program without regard for other environmental concerns (Kosoy \& Corbera, 2010; Luck et al., 2012; van Hecken \& Bastiaensen, 2010). For example, participants in carbon-credit programs may produce low-cost carbon at the expense of food production and livelihood security, which emphasizes possible perverse incentives by such environmental market interjections (Jack et al., 2009; Muradian et al., 2010). The problem of new externalities is especially applicable to PES designs that award contracts based on a small set of pre-identified criteria, and less applicable to designs that involve scrutiny for multiple attributes (e.g., Stoneham et al., 2003).

The problem of new externalities often applies to reforestation or afforestation programs, wherein plantations of fast growing (and often non-native) trees such as eucalyptus are commonly promoted 
because their fast growth satisfies carbon sequestration goals, but also consume much water, cause considerable soil loss and sedimentation, and may provide little habitat for biodiversity, even at maturity (Farley et al., 2005; Jackson et al., 2005; Jindal et al., 2008; Bremer \& Farley, 2010). Such failures have been elaborated by Flores et al. (2009), who discuss the struggles of NGOs against the Plantar Forestry Project in Brazil. Additionality requirements and narrowly targeted payments may also lead to unintended environmental consequences (Flores et al., 2009; Bagri et al., 1999). Furthermore, PES payments can, if unchecked, lead to further perverse incentives when those who do not qualify to participate in a given program engage in undesirable activities, like deforestation, in order to be eligible for the PES program (Sommerville et al., 2009; Wunder et al., 2008).

\section{Misplaced rights and responsibilities, "Polluter is paid"}

By providing payments for particular actions, incentive programs specify or imply a set of rights and responsibilities that may change the way people perceive entitlements and appropriate actions. In the ecosystem services literature, researchers have noted that PES might shift our understanding of our rights and responsibilities towards ecosystems (Solazzo et al., 2015; Mauerhofer et al., 2013; Chan et al., 2012). Most PES systems are structured such that beneficiaries of ES pay those directly responsible for an ecosystem ("ES providers") not to degrade (e.g., downstream water users pay upstream farmers to reduce sedimentation and eutrophication of waterways). Such a structure sends an implicit signal that people have the right to degrade unless paid not to do so (Polasky, 1997). In short, the responsibility to care for or conserve the ecosystem and the services it provides is shifted from those directly responsible for the ecosystem to those paying for the ES. Responses that include the disappointment effect, loss aversion, and negative reciprocity can change how stewards and benefactors of environmental services understand their rights and responsibilities towards ecosystems (Fehr \& Falk, 2002; Fehr \& Gächter, 2001; Frey \& Oberholzer-Gee, 1997). For example, ES providers may be less likely to continue an action after an introduced financial incentive is removed because they have learned to feel entitled to receive this compensation, and/or because they perceive that a relationship has been violated. This problem is applicable to any program that funds would-be polluters/degraders to refrain from polluting or degrading, particularly if payments only apply to those who were previously polluting/degrading, as commonly required for additionality (hence "polluter is paid" rather than "steward earns" as in Gómez-Baggethun \& Ruiz-Pérez 2011); it applies less to programs that fund active positive stewardship (e.g., encouragement to create new pollinator habitat or nest sites).

There are many examples of changing perceptions of rights and responsibilities in response to incentives, also associated with motivational crowding out (see 3 below; Gneezy \& Rustichini, 2000; Fehr \& Falk, 2002). As an example of disappointment regarding PES, in a carbon project in Uganda, participants who did not make required changes prior to monitoring were frustrated when payments were not received or there was a delay in compensation, which undermined overall goodwill and trust (Dougill et al., 2012). Similar effects may also occur on the consumer side of market-based conservation programs. Igoe (2013) describes how participating in activities like purchasing products with environmental certifications or acres of rainforest allows consumers to purchase their personal "environmental redemption", meaning that they may feel like they have fulfilled their environmental responsibilities and do not need to participate in further conservation activities.

\section{Motivational Crowding out, "Money breeds mercenaries"}

Whereas we might hope that adding a monetary incentive simply adds to existing motivations for 
conservation, there is also a danger that the new monetary incentive provided by PES programs can undermine existing "intrinsic" or altruistic motivations. Much has been written describing this motivational "crowding out" in the context of PES (Vatn, 2010; Luck et al., 2012; ). Considerable evidence for this phenomenon has been found in experimental psychology (e.g. Frey \& OberholzerGee, 1997; Reeson \& Tisdell, 2008; van Noordwijk et al., 2012). Experiments confirm that participants receiving only social incentives (no payment) often expend more effort than those receiving payments, or than those offered both incentives (Heyman \& Ariely, 2004). While most of the evidence to date does not focus on conservation activities, there is evidence of motivational crowding out in PES programs (Rode et al., 2015). Of particular concern is the fact that the displacement of intrinsic and altruistic motivations may be difficult to reverse (i.e., after the removal of the monetary incentive) (Gneezy \& Rustichini, 2000). This problem applies to any program offering a payment, but it may be less applicable when payments are co-payments or clearly lower than opportunity costs (because ES providers must retain intrinsic motivations to justify participation (Kosoy et al., 2007)).

Although it has received less attention in the PES literature, motivational crowding out can have a social dimension as well. Some stakeholders may undertake stewardship actions for stated 'moral' reasons partly to gain social approval or avoid social disapproval, or simply to conform to social norms (Kerr et al., 2012). However, if people are paid for such actions (or see others getting paid for the same action), the social incentive diminishes as it becomes hard to distinguish a moral motivation from a mercenary one (Fehr \& Falk, 2002). Similarly, Bowles (2008) suggests that policies designed for self-interested citizens may undermine moral motivations. By focusing on economic arguments, we may diminish the total number of motivations for conservation (Olmsted et al., in prep), a concern because conservation efforts will likely be more successful with multiple arguments in their favour (Redford \& Adams, 2009). Wunder (2005) explains how strict additionality requirements can signal that non-monetary motivations for conservation are not valued by excluding conservation-minded people who may already be engaged in conservation activities for non-monetary reasons.

There is some evidence of motivational crowding-out from the PES literature. In experimental settings with hypothetical farmers, Kits et al. (2014) observed small crowding-out effects via reduced participation after removal of payments. Similarly, in their review of eighteen empirical studies Rode et al. (2015) found evidence of motivational crowding out (and to a lesser degree, crowding in). More recently, De Martino et al. (2015) paradoxically found that higher monetary awards induced less participation of conservation-minded landowners in a hypothetical PES, suggesting a crowding-out effect.

\section{Project Efficiency and Equity, "What about me?"}

There is an inherent tension between structuring a program to achieve maximal conservation gain for the least money versus providing needed funds equitably across potential participants. Conservation program efficiency is often sought via targeting participants who offer the greatest 'additionality'effectively the greatest conservation return on investment. Efficiency may also impede equity when program designs unintentionally exacerbate barriers to participation for poorer landowners, including land tenure and requirements to hire foresters to complete applications (Pagiola, 2008; Anderson \& Zerriffi, 2012). The tradeoff between these two desirable attributes appears to be applicable to all PES designs.

The PES literature provides many examples of such tradeoffs. Programs may seek efficiency at the cost of equity when they seek out the most ecologically important or most degraded land (Pascual et 
al., 2010). Other common strategies to reduce PES program costs, such as requiring minimum commitments of land or resources to participate, favour including fewer ES providers responsible for larger parcels of land over many smaller-scale providers (Anderson \& Zerriffi, 2012). In an attempt to optimize multiple conservation goals in a PES in the Andes, researchers found substantial tradeoffs between maximizing land enrolled and number of farmers participating - the most cost-effective conservation resulted in substantially uneven payments to participants (Narloch et al., 2011). Targeting particular land for conservation or changing management practices yields better (environmental) results than including land at random or maintaining existing practices (Narloch et al., 2011; Pascual et al., 2010). However, this can exclude people in some areas and those who are already engaging in conservation activities. PES programs that aim for highly efficient service provision outcomes and ignore equity considerations may reinforce existing power structures as well as inequalities in access to resources (Pascual et al., 2010); they may even undermine the effectiveness of PES programs for conservation (Pascual et al., 2014). In Costa Rica's national PES program, despite the addition of explicit social goals and associated requirements to include less wealthy and more vulnerable Costa Ricans, participants continued to be disproportionately wealthier, more educated landowners (Porras et al., 2013). On the other hand, the PES program in Costa Rica arguably also reduces its environmental efficiency while increasing equity by allocating $26 \%$ of its funding to PES in indigenous territories where there is little risk of deforestation (Porras et al., 2013).

\section{Burden of monitoring, "Cheating pays, so pay for policing"}

If participants engage in a program primarily for monetary benefit, there is an unavoidable incentive for ES providers to cut corners or shirk responsibilities, which has led to costly on-ground monitoring to ensure that participants are doing as they should. While monitoring of overall impact is important to understand the effectiveness of various programs, monitoring, and an often rigid accountability framework consumes a large fraction of the costs of carbon credit payments (Wittman et al., 2015). In addition to concerns about cheating, PES may require detailed monitoring for reports to funders or beneficiaries or for accounting purposes (Wittman \& Caron, 2009). More broadly, an overemphasis on monitoring, auditing, and achievement of quantitative metrics can undermine organizational autonomy and professional values, yielding several kinds of unintended effects (Shore \& Wright, 2015). This problem is applicable to any PES program involving payments, but much less so when the payments are token (small relative to opportunity costs), in-kind, or reimbursements for expenses incurred, due to the associated reduction in incentives or opportunities to cheat.

Particularly for carbon sequestration projects, which generally require detailed accounting, monitoring costs have subtracted from other program goals. When an NGO in Guatemala adopted PES as a mechanism to fund its reforestation work with small-scale farmers, several unanticipated consequences occurred: funds were diverted from development activities to pay for costly outside consultants with the needed technical skills for carbon accounting, and the NGO expanded from its focus on small scale farmers to include those with larger land holdings (which eased the burden of monitoring) (Wittman \& Caron, 2009). Thus, burdensome monitoring not only presents costs but can also function to exclude many small-holder farmers from participating, particularly when auditors are paid by the farmer, as in Costa Rica's national PES program.

\section{Limited applicability, "A Coasean solution ... for a non-Coasean world"}

PES are also limited as a solution to environmental problems because they are only applicable to relatively rare cases (Wunder, 2013). Although Wunder points to several relevant requirements, much 
can be summed up by recognizing that PES-as ideally conceived-are effectively two-party negotiation solutions in a world where two-party problems are rare. Here we refer to Coasean theory, which posits that environmental externalities can be solved via the clarification of property rights, which would allow affected parties (the impacted and the impacting) to negotiate with one another in a free market system (Coase, 1960; Tietenberg, 2003; Harris, 2002; Russell, 2001; Hanley et al., 2001; Perman et al., 2003). Coase argued that precise allocations of property rights and the absence of any costs of information or negotiation would allow two parties to arrive at an advantageous outcome (Dixit \& Olson, 2000; Coase, 1960). Such negotiations should result in Pareto-optimal outcomes including the human experience of environmental harms (Cheung, 1970; Coase, 1960).

The problem is that such solutions apply only to the few cases in which a given environmental externality (e.g., water quality degradation) affects a single party or a cohesive set of parties. In cases of multiple affected parties (e.g., firms and also human communities), the benefits of ES mitigation actions often cannot be recouped by a sufficiently cohesive group that such private solutions will occur spontaneously. In many PES, governments have stepped forward with a Pigouvian solution (Engel, 2016) distributing funds from the public purse to protect public benefits. Because this generally requires large new sources of revenue (e.g., taxes), such government action does not often happen at large scales. As such, the types of actors involved in PES-and thus the sources of funds and the scope for application of PES-are often quite limited. This problem is not associated with any particular application, but rather the paucity of applications in relation to the frequency of environmental externalities.

In line with this argument, there has been relatively little corporate involvement in PES, despite a rise in interest in environmental sustainability by manufacturers and retailers globally (Dauvergne \& Lister, 2012). Considering the role that firms have played in impacting the environment, firm participation in conservation is appropriate (Dixon \& Challies, 2015). Yet firms face a high degree of risk and uncertainty when entering new markets in the form of sustainable initiatives (Dixon \& Challies, 2015). In the case of PES, firms are often unfamiliar with the nexus of conservation, social development and investment finance (Agrawal et al., 2011; Corbera \& Schroeder, 2011; Dixon \& Challies, 2015). Limited private sector involvement may reflect the considerable costs and uncertainty associated with PES, which can be magnified in the context of low governance capacity (Matthews et al., 2014; Rendón-Thompson et al., 2013; Van Noordwijk et al., 2014; Hajjar, 2014). Recently, firms have become more involved in PES through REDD+ activities, with firms comprising nearly $40 \%$ of organizations engaged in preventative deforestation pilot projects globally (Gallemore and Munroe, 2013). While firms have been directly involved in PES advocacy networks, particularly in the case of REDD+, they remain at the edge of the policy community discussion, with limited engagement at the project level (Moeliono et al., 2014: Gallemore \& Munore, 2013). Policymaker understanding of firm participation in PES remains limited, including motivating drivers and investment behaviors (Levy \& Newell, 2005).

\section{Top down prescription, "Agency knows best"}

Many PES programs fund particular actions on a one-size-fits-all basis, which incurs the risk that would-be participants might recoil from such prescriptions due to conflicts with their own values or restrictions on their creativity and wisdom as stewards of the land. Dictated by regulators or third parties, PES regulations may thus not fit with the values and practices of ES providers. Such outside prescriptions are often far less attractive than home-grown solutions (e.g., the "follow the bright spots" approach, Heath \& Heath, 2010). This problem applies to any design that dictates narrowly the kinds 
of actions that are eligible for payment, and it applies less to PES designs that invite suggestions for actions (e.g., Stoneham et al., 2003).

Farmers and other landowners often resist inflexible prescriptions, which seem to conflict with their values, and which deny their agency as effective stewards of the land (Chan et al, 2015). In one case, 'no touch' rules for a riparian buffer PES in the US Northwest conflicted with farmers' values to actively manage and care for their land (Chan et al., 2015). In another PES project, farmer buy-in was improved when it adapted to farmers' language and culture, e.g., framing ES as a product that farmers produce and a point of pride (Wynne-Jones, 2012). Farmers often prefer conservation actions that visibly demonstrate success or productivity-e.g., fences are preferred to overgrown buffers (Burton, 2004) (despite this, unmanaged buffers are a common feature of PES).

One reason for the conflict between ES providers and PES programs may derive from the values articulated by these programs and conventional environmental conservation (Vatn, 2005; Olmsted et al., in prep; Chapman et al., in prep). ES literature has generally focused on intrinsic and instrumental values of nature, though the latest IPBES framework makes key steps towards acknowledging a greater diversity of relationships between people and nature (Díaz et al., 2015; Chan et al., 2016). Agrarian values, for example, are often centered around the relationships between farmers and the land they work, so-called "relational values" that can also include instrumental and intrinsic components (Carlisle, 2013; Smith, 2003; Chan et al., 2016).

\section{Solving the problems}

Although many PES programs are vulnerable to the above critiques, some are less vulnerable, sometimes by accident. For example, Kosoy et al. (2007) show that many Central American farmers in their sample participated in PES programs even though payments were lower than opportunity costs, which indicates that the program is successfully 'recruiting' inherent motivations. Outside the PES literature, Wilcove \& Lee (2004) showed that many US landowners can forego opportunities for private gain (specifically, regulatory relief associated with endangered species legislation) under programs designed explicitly to foster trust and goodwill. Program participants who are investing considerable time and effort without full compensation, might experience the avoidance of cognitive dissonance (Cooper, 2007; Festinger, 1962). By this psychological process, those participating despite incurring costs (i.e., being compensated less than their opportunity costs) are likely to subconsciously justify their contributions (or foregone opportunities) as consistent with their stewardship values and/or identities, thus reinforcing those values and identities. There is ample evidence of this effect from psychology, e.g., homeowners told that they would be featured in a newspaper for their energy conservation achievements subsequently reduced their energy consumption (Pallak et al., 1980). Even more interestingly, the homeowners' conservation efforts increased after (later) being told that the newspaper could not run the article-apparently because the process had cemented their identity as a conserver of energy (Pallak et al., 1980; Cialdini, 2007).

Perhaps PES could similarly crowd in existing motivations. One design that might facilitate this is the reverse auction, which includes a competitive bidding process that encourages ES providers to bid low, particularly when bids are closed (i.e., to have a greater chance of being funded) (Stoneham et al., 2003). Such reverse auctions are like other PES except that instead of a one-size-fits-all determination of payments for prescribed actions, participants propose both actions and requested payments in their bids; bids are then chosen by the program administrator based on cost-effectiveness (Vickerey, 1961; Ajayi et al., 2012; Bryan et al., 2016). Since it is now clear from the evidence of 
motivational crowding out (Rode et al., 2015) that many landowners have intrinsic motivations for stewardship actions, it seems quite likely that ES providers would undervalue their time in bids, because the chosen actions are likely to be ones they wished to undertake anyway (e.g., clearing invasive vegetation, or fencing to keep livestock from degrading streams, which might be 'intrinsically' desirable for both self- and other-oriented reasons). Ironically, Stoneham et al. (2003) assumed that reverse auctions would reveal the costs of management, but in a context of intrinsic motivation, bids are likely to understate the costs (which would help explain how in the Australian state of Victoria achieved a cost-savings of approximately seven times, relative to a fixed-price payment) (Stoneham et al., 2003). Underbidding ES providers would have the same crowding-in potential as noted above. An analysis of real programs in Tasmania, Australia revealed that such programs benefited landowners and also facilitated shifts in motivations and values (Zammit, 2013).

Such design features might be further leveraged to intentionally accomplish the value-change that is likely essential for sustainability (Table 1; sections below). First, program communication could explicitly label funding as awards for good stewardship. By explicitly naming desired values in this way, and publicly recognizing individual actions and commitments, we can 'grow' leadership identities and also encourage future behaviours consistent with those identities (Heath \& Heath, 2010; Cialdini, 2007). Even tiny tweaks in program wording can apparently affect stated desirability of PES programs (Clot et al., 2017). Second, by designating funding based on such identities as illustrated through past actions, we might further enhance these steward-growing effects.

Many of the seven problems stem partly from what we might see as an unhealthy obsession with individual-level additionality (Goldman-Benner et al., 2012). This obsession may stem from the logic that PES, as with all subsidy programs, are vulnerable to cost inefficiencies via paying for actions that ES providers would have undertaken even without the program. We would argue, however, that the focus on each individual misses the point. In addition to equity, what matters is that the program as a whole realizes conservation goals efficiently and that it sets the stage for future stewardship through value consolidation and norm change. Cost-effectiveness at the scale of the project can be enhanced by program designs that attract a large number of bids (thus incorporating many low-cost providers) that leverage existing motivations (e.g., for payments less than the full opportunity costs), and which crowd-in inherent motivations rather than crowding them out (thus securing future stewardship). 


\begin{tabular}{|c|c|c|}
\hline Problem & Suggested Shift & Tools for a New Approach \\
\hline I. New externalities & $\begin{array}{l}\text { Pay for services } \rightarrow \text { Reward } \\
\text { stewardship }\end{array}$ & $\begin{array}{l}\text { - Multiple ecosystem service targets } \\
\text { - Flexibility in supported activities }\end{array}$ \\
\hline $\begin{array}{l}\text { 2. Misplaced rights } \\
\text { and responsibilities }\end{array}$ & $\begin{array}{l}\text { Beneficiaries pay } \rightarrow \text { We all } \\
\text { contribute }\end{array}$ & $\begin{array}{l}\text { - Payments for stewardship, not } \\
\text { avoided pollution/degradation }\end{array}$ \\
\hline $\begin{array}{l}\text { 3. Motivational } \\
\text { crowding out }\end{array}$ & $\begin{array}{l}\text { Financial incentive } \rightarrow \\
\text { Supporting stewards }\end{array}$ & $\begin{array}{l}\text { - Co-payments } \\
\text { - In-kind payments }\end{array}$ \\
\hline $\begin{array}{l}\text { 4. Project efficiency } \\
\text { and equity }\end{array}$ & $\begin{array}{l}\text { Small-scale } \rightarrow \text { Landscape scale } \\
\text { (monitoring and accounting) }\end{array}$ & $\begin{array}{l}\text { Rewards and support for existing } \\
\text { good stewards }\end{array}$ \\
\hline $\begin{array}{l}\text { 5. Burden of } \\
\text { monitoring }\end{array}$ & $\begin{array}{l}\text { Focus on compliance } \rightarrow \text { Focus } \\
\text { on norms, values and learning }\end{array}$ & $\begin{array}{l}\text { - Peer monitoring } \\
\text { - Landowner-identified valued } \\
\text { activities (e.g., via reverse auctions) }\end{array}$ \\
\hline $\begin{array}{l}\text { 6. Limited } \\
\text { applicability }\end{array}$ & $\begin{array}{l}\text { Two-party negotiations over } \\
\text { externalities } \rightarrow \text { Individual and } \\
\text { collective responsibilities }\end{array}$ & $\begin{array}{l}\text { - New institutions with calibrated } \\
\text { funding duties (e.g., offsets) to } \\
\text { engage all supply chain actors }\end{array}$ \\
\hline $\begin{array}{l}\text { 7.Top down } \\
\text { prescription }\end{array}$ & $\begin{array}{l}\text { Agencies decide } \rightarrow \text { Place- } \\
\text { based solutions }\end{array}$ & $\begin{array}{l}\text { - Landowner-identified valued } \\
\text { activities (e.g., via reverse auctions) } \\
\text { - Participatory program design }\end{array}$ \\
\hline
\end{tabular}

Table 1. Toolbox for a reimagined PES. Seven fundamental critiques levied at PES programs ('problems') are paired with approaches to solutions, including both proposed conceptual shifts and example design criteria ('tools') to enact those. Overarching shifts in program framing and communication may complement the proposed design changes (e.g., payments as awards rather than incentives). Appropriate tools will be highly context-dependent, but the hope is that the proposed conceptual shifts will inspire practitioners to improve or develop new methods and tools to address key sustainability challenges via PES.

Imagine a program designed as above. It would substitute fixed payments for 'additional' outcomes with publicly conspicuous co-payment awards for sustained stewardship commitments, thus replacing an implicit message of "If you do $X$, we'll pay you $\$ Y$ " with "Land stewardship leader: How can we help you do even more?". Imagine further that the program was funded not by beneficiaries of threatened ES, but by the whole supply chain complicit in such impacts, including the retailers and consumers of the goods whose production incurs impacts (more details below). In the admittedly aspirational section below, we outline how such a conceptual shift could be realized via a suite of program design features, which might address the seven categories of problems facing PES. While the proposals below could work together synergistically, they could also be implemented separately as appropriate for and effective in different contexts. 


\section{Reward Stewardship, Not Particular Actions [vs. New Externalities]}

By rewarding stewardship instead of particular pre-defined actions or outputs, programs could close the loopholes that inevitably arise with any fixed metric for payment, thus reducing the risk of new externalities. By maintaining an adaptive evaluation process and rewarding patterns of behavior, programs might escape Goodhart's Law and encourage short-term and long-term stewardship (Newton, 2011).

Some programs are already functioning as a public recognition for overall stewardship-if unofficially. For example, more than a third of PES participants surveyed in the San Carlos region in Costa Rica said that recognition as someone who cares for the environment was an important benefit they received from participating in the program, and $68 \%$ reported both recognition and environmental benefits, whereas only $53 \%$ mentioned economic benefits (Anderson et al. in prep). Similarly, Kosoy found that many providers from a watershed PES in Central America perceived the payment as an 'apoyo' or support for actions they would carry out anyway (Kosoy et al., 2007). Chapman found a parallel result among participants in Costa Rica's PES, where most providers describe the payments as an 'ayuda', a type of help or assistance to protect the forest and support rural landowners (Chapman et al., in prep). The 'Flowering Meadows' PES in France focuses on outcomes while leaving farmers flexibility to determine means, allowing farmers to demonstrate their competence while also helping to change farmer's perspectives on biodiversity (Fleury et al., 2015).

A focus on stewardship might allow for greater flexibility in implementation. Rural landowners in Washington State valued flexibility and the option to adapt PES program conditions to their particular farm or land, for example, by varying the width of riparian buffers or allowing working buffers that integrate riparian habitat and production (Chan et al., 2015). Flexibility not only makes PES programs more attractive to land managers but also allows them to apply their place-specific knowledge to achieve program goals, e.g., targeting riparian plantings to maximize shading of rivers or filtering of runoff (see also 7 below). For example, programs where farmers propose their own solutions to achieve ES goals or are involved collaboratively with other stakeholders to define the goals and means may be more motivating (Fleury et al., 2015). It is not only important to allow flexibility to find creative solutions in order to find synergies between conservation and land managers' other goals, but also because the process of problem-solving is in itself enjoyable and motivating for many (Kaplan, 2000).

\section{Pay stewards and we all contribute, distributing rights and responsibilities inclusively [vs. misplaced right and responsibilities]}

By paying for land managers to act as stewards rather than polluters, and by sharing the burden of payment across the supply chain, programs would distribute rights and responsibilities in a manner more conducive to sustainability (Figure 1). Such programs would avoid sending the signal that ES providers are free to pollute/degrade unless paid not to do so, or that ES beneficiaries are responsible for securing desirable behavior upstream. Instead, ES providers would be expected to bear some of the costs of management, and ES beneficiaries would not be solely responsible for ensuring continued ES provision. It is especially crucial to avoid putting the responsibility on ES beneficiaries when they are poor or disempowered, or when they have long relied upon the ES (as with indigenous peoples and clean water, wildlife, etc.). Furthermore, such programs would also assign responsibility to the rest of us who are complicit in such production processes, e.g., as the retailers and consumers of goods, sending the signal that it is unacceptable to profit from production that incurs ecological degradation 
without mitigating those harms.

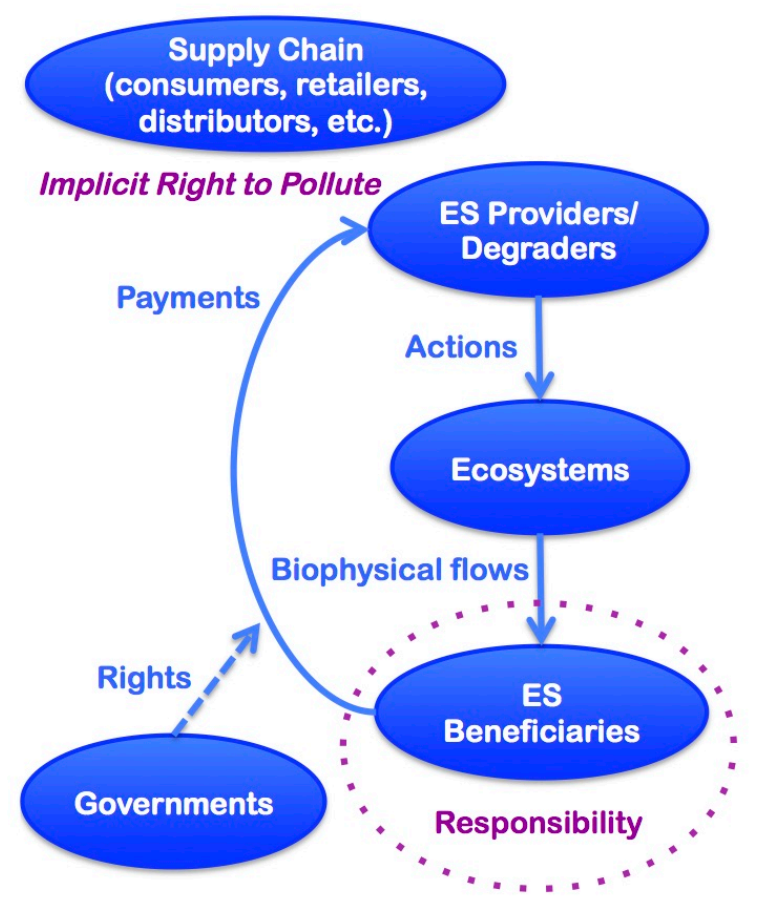

A. Narrow-Responsibility PES

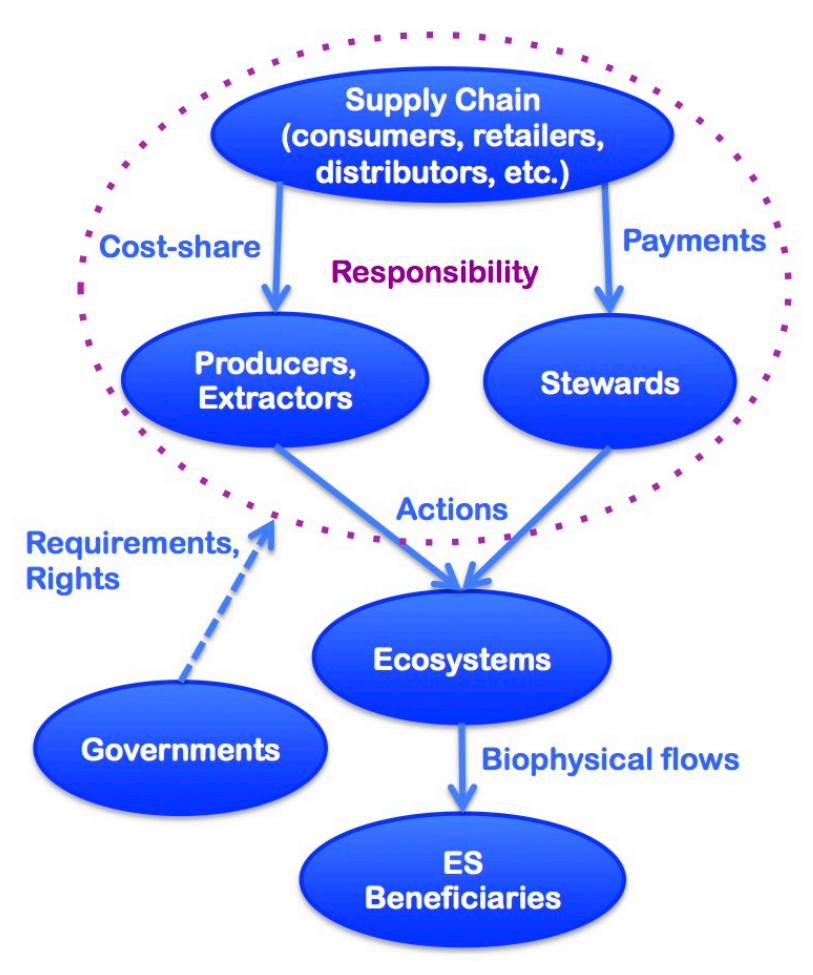

B. Responsibility-Extending PES

Figure 1. The current and proposed new models for payments for ecosystem services (PES), including their explicit and implicit distribution of responsibilities. A. Current models implicitly place the responsibility on beneficiaries of ecosystem services (ES) to protect ecosystems for the continued delivery of benefits, implicitly giving producers, extractors, and the supply chain the right to pollute (and the right to receive payments for ceasing to pollute, which penalizes those who were already acting as good stewards). Such rights and payments may undermine sustainability. B. In contrast, our reimagined PES puts the responsibility on producers, extractors, and the supply chain to mitigate their impacts, including by paying ES stewards to protect ecosystems. These responsibilities and payments may foster value and norm change towards sustainability. Governments have an important role to play, but they need not lead. The distributed responsibility may be crucial for achieving sustainability. The incipient movement called CoSphere (a Community of Small-Planet Heroes, Ecologically Regenerating Economies) embodies this logic of responsibility-taking.

An even sharing of responsibilities might be achieved in several different ways. First, 'policy mixes'where different instruments work together-can distribute responsibilities and also rights to 
landowners, as is the case in Costa Rica where a ban on deforestation confers responsibilities while the nationalized PES program confers rights (Porras et al., 2013). Second, broad responsibilities for environmental degradation might also be indicated by paying only part of the costs borne by PES participants (see solution 3), and by inviting or even requiring firms and/or individuals to mitigate said degradation via co-funding a PES program (see solution 6). Our proposal to pay only part of the costs (co-pay) bears similarities to the notion of co-investment in environmental stewardship (CIS), discussed by van Noordwijk \& Leimona (2010). We agree wholly with van Noordwijk \& Leimona's conclusion that "A language of CIS, 'co-investment' and 'shared responsibility' may be more conducive to the type of respect, mutual accountability, and commitment to sustainable development that is needed" because it "retains reference to social exchange rather than financial transactions" (p. 17).

\section{Co-pay (sometimes in-kind), complementing and 'crowding in' intrinsic motivations [vs. crowding out]}

By paying only a part of a participant's opportunity costs, a PES program might crowd in intrinsic motivations rather than crowd them out. If Chan et al.'s (2016) contention is true, that landowners, and farmers in particular, already possess a wide range of stewardship values ('relational values', to be distinguished from instrumental and intrinsic values), there should be abundant opportunities to crowd. We already know that non-cash/in-kind payments (e.g., supplying needed tools or resources, including technical assistance) are less prone to crowding out inherent motivations (Ariely, 2008; Leimona et al., 2015). This proposal goes even further, aiming for crowding in. By paying only a portion of the total costs, 'co-payments' should ensure that ES providers would participate only if they are subsidizing the project with their own time or resources. This commitment of one's own time or resources triggers the avoidance of cognitive dissonance to consolidate stewardship values (because only a commitment to stewardship can dissolve the dissonance of bearing costs for actions that don't yield profits). Furthermore, co-payments should preserve any motivations based on social approval (Fehr \& Falk, 2002; Lapeyre et al., 2015) (because the action may still be perceived as moral rather than mercenary). Note that this proposal is decidedly at odds with prevailing economic advice about incentive schemes, which includes prescriptions that payments should exceed opportunity costs (Wunder, 2013), and that cash payments are preferable (e.g., Ferraro \& Kiss, 2002).

As already noted, some programs are already functioning in the ways suggested. First, several PES in Central America are paying less than opportunity costs (Kosoy et al., 2007). Second, there are indications that Costa Rica's PES is functioning at least partially as a recognition of good stewardship (Anderson et al., in prep.). Third, technical assistance associated with landowner incentive programs can be both motivating (Chapman et al. in prep; Zammit, 2013) and productive in securing stewardship outlooks and future-oriented behaviours (Wilcove \& Lee, 2004; Vignola et al., 2012).

There is some evidence in the literature that PES can act to reinforce non-economic motivations for conservation, thus "crowding in" rather than "crowding out" (Rode et al., 2015; Lapeyre, et al., 2015). Financial incentives including PES have the potential to reinforce or reduce intrinsic motivations and social norms such as pro-conservation norms, depending in part on how institutions and initiatives are structured and the context in which they are implemented (Bowles, 2008; van Noordwijk et al., 2012). For example, in Ireland a small tax greatly reduced plastic bag use by identifying such use as an antisocial behaviour (Bowles, 2008). Small incentives can also encourage people to take actions they support but do not prioritize, as was demonstrated when an offering of a small amount of lentils increased child immunization in India (Banerjee et al., 2010). In this way, PES payments could act like a nudge to incite/inspire people to act based on existing motivations for conservation (Olmsted et al., 
Chan et al., Re-Imagining PES

in prep).

\section{Forget small-scale additionality; focus on efficiency via attractiveness and norm change [vs. efficiency/equity dilemma]}

If programs were designed to pay participants for good behaviours (both past and future), individual parcels may not achieve additionality in the short term, but the program might be more efficient in the long run. Long-term success would stem from the activation and reinforcement of stewardship values (as above), and from building trusting relationships between ES providers and program officials via an inclusive program that feels fair. Trust, after all, is central in such programs (Goldstein, 2005; Kerr et al, 2012). Including ES providers who would do the desired action without the program (or who are already doing it) would mitigate the perverse incentive for ES providers to pretend that they would not have done the action without the program (a self-reinforcing representation), or to undermine past efforts to make room for new additionality (e.g., setting fire to forests so as to qualify for a new set of payments for forest regrowth). Under an award model, it is acceptable and appropriate to pay ES providers for actions that they already wished to do: that is precisely how a program leverages small payments (less than opportunity costs) into full actions, and how it might build and consolidate stewardship norms.

Some programs have adopted this approach, at least partly. For example, some programs have intentionally chosen payments that are equitable across landowners regardless of the conservation opportunity of their land, in the intent to build goodwill (Chopra et al., 2012). In another Costa Rican example where the PES concept was more familiar, ICE, the national energy utility managing a dam was eager to pay upstream farmers to reduce sedimentation (Vignola et al., 2012). Rather than differentiated payments or even equitable ones, the farmers revealed that technical assistance was more desirable and seen as more fair; ICE was happy to comply (Vignola et al., 2012).

Our argument to forget additionality at the scale of the individual participant, focusing instead at the scale of the program, aligns directly with Pascual et al.'s (2010) definition of additionality as the "difference between the gross welfare effects induced by the scheme on society (...) and the total cost incurred to implement it" (p. 1239). 'Gross welfare effects' should also include the pleasure that ES providers receive from receiving payment to take actions they wished to do anyway, and the widespread happiness with a fair and equitable program.

\section{Employ intrinsic motivations and peers to reduce monitoring needs [vs. burden of monitoring]}

ES provider incentives to cheat are greatly reduced when providers make a publicly conspicuous commitment. The design of co-payments, which intend to ensure that the program is attractive only to those with intrinsic incentives, thereby greatly reduces the individual motivation to cheat. Any public acknowledgement of a commitment to a stewardship identity would greatly enhance this individual motivation to comply via social approval/disapproval (Cialdini, 2007). In such contexts, people can 'police' each other, as occurs with universities that have adopted honour codes against plagiarism. Given sufficient intrinsic motivations to comply, exhibiting trust in the form of an honour code and an intentionally low-level of official monitoring might engender reciprocal trust and trustworthiness from participants. Such peer monitoring could be complemented by coarse-scale monitoring of the aggregate outcomes of the program, which would be important for ensuring additionality at the 
program-scale (see 4). The multiple levels of monitoring aligns with calls for polycentric governance systems (Biggs et al., 2012).

Peer monitoring has been employed in farm management and shown to be effective in both US and Brazilian cases. Carlisle's (2015) study of organic certification found that informal peer-to-peer monitoring and participation in a self-organized community were more important in ensuring compliance with organic standards than official regulation and monitoring. In addition to reducing costs, flexible and peer-based monitoring can encourage learning and innovation. In one case, inspectors able to offer advice and connections to other growers could have served as extension agents to help growers new to organic standards; new standards prohibited such assistance from inspectors (Carlisle, 2015: 16). When firms participate in PES as ES suppliers, community-based monitoring may provide opportunities for community participation in partnership with or as monitors for firms, further incentivizing positive innovation on the part of private sector actors. Despite research suggesting that community participation in Monitoring Reporting and Verification (MRV) results in highquality, cost-effective assessments and increased legitimacy (Danielsen et al., 2013; Danielsen et al., 2005; Larrazábal et al., 2012; Brofeldt et al., 2014), community participation in monitoring remains underdeveloped (Danielsen et al., 2013; Pratihast et al., 2013). Reimagining PES as suggested here might involve increasing community monitoring.

\section{Include funders seeking to mitigate their impacts, thus involving parties throughout the supply chain [vs. limited applicability]}

Whereas traditional PES programs are designed for private or public beneficiaries to secure private or public benefits, a program designed to enable funders to mitigate impacts and/or pay "user fees for nature" could potentially involve large portions of supply chains. As we described above, firms can be hesitant to get involved in conservation initiatives like PES for a variety of reasons. While full treatment of this idea is beyond the scope of this paper, we see hope in uniting an offset funding model with a PES delivery mechanism (Chan et al., 2017 in press). A single payment, low-overhead program option that allowed a firm to not only mitigate their impacts across their entire operation (not just a single product), but also then identify their brand with an entire community or movement of "conscientious consumers and producers", could be attractive to firms seeking simple ways to become more sustainable that are low-risk but potentially high-impact.

Such a broadening of the funding for environmental stewardship would seek to recognize that, insofar as the whole supply chain benefits from the production of the product that has environmental impacts, the whole supply chain should share in reducing those impacts. Involving the supply chain in this manner might work against the "race to the bottom", wherein producers are incentivized to cut corners in environmental stewardship in order to supply low-cost goods, because many costs of environmental damages are not currently internalized into the cost of products. Obviously, involving the supply chain in preventing environmental degradation is neither novel in itself nor easy to achieve, and a full proposal is beyond the scope of the current article. Here we briefly contemplate a possible novel pairing of supply chains with PES.

This model we propose is complementary to certification. Whereas certification (e.g., organic) seeks to enable consumers to contribute to environmental improvements by paying a price premium for a certified product, the premium paid by consumers largely goes towards maintaining a distinct but parallel supply chain (to the conventional product), with relatively little for farmers changing their environmental management. Insofar as certified products often have a market share much smaller 
than the conventional product, the loss of economies of scale throughout the supply chain can result in a highly inefficient vehicle for consumer participation in production. A system of offsets for environmental damages should alleviate these inefficiencies (Chan et al., 2017 in press), enabling consumer funding to effect management via PES on both certified and conventional fields. Such an initiative is underway (www.CoSphere.net), and in theory would allow consumers to compare different levels of environmental impact associated with comparable products, and to contribute to paying for, and thus internalizing and taking responsibility for, each product's environmental impacts. Only when it is easy, enjoyable and affordable to enact personal responsibilities for distant environmental impacts is it likely to become normal to do so (Chan et al., 2017 in press).

\section{Invite place-based solutions, inspiring agency [vs. top down prescription]}

If program officials do not dictate appropriate stewardship actions, but rather invite ES providers to propose what they would like to do (that contributes to specified environmental outcomes), there's an immediate inspiration of the creative agency of producers as stewards. One of the more powerful leverage points for sustainability is to enable self-organized solutions (Meadows, 2009). In principle, such payments need not be constrained to farmers and landowners, but open to a wide range of citizens, organizations, and even possibly firms to engage as stewards and distinguish themselves as such.

As described above, reverse auctions generally enable a greater degree of agency among PES participants by funding a diversity of possible actions. Such flexibility may be partly responsible for the considerable cost-savings that seem to result from such programs (Stoneham et al., 2003; Ajayi, 2012), in part because ES providers may be choosing actions that they already wish to undertake, such that they are willing to perform conservation actions for compensation less than opportunity costs. A further strategy is to incorporate the preferences of potential participants. Depending on the particular social and ecological context participants may prefer payments to be communal or individual, in-kind or cash, closely tied to concrete actions or focused on outcomes with flexibility for implementation (Kaczan \& Swallow, 2013; Kolinjivadi et al., 2015). For example, Mexico's national PES program went through substantial changes between design and implementation, as local actors imprinted their own concepts and priorities, leading to a final design that was a better fit with local needs (McAfee \& Shapiro, 2010).

Novel and flexible forms of PES could be more motivating to farmers and other ES providers. Rather than expecting people to adopt PES for either altruistic or economic reasons, we might use a form of participatory problem solving so that ES providers can look for options that are good for the environment and improve their lives, land or livelihoods. Such an approach has been suggested by Kaplan in the context of green consumerism and individual responsibility for environmental impacts (Kaplan, 2000). As an example, the successful Vittel PES case in France involved substantial participation by farmers and other stakeholders in the region to design the program rules and structure (Perrot-Maitre, 2006). Also from France, the 'Flowering Meadows' PES program involved participation from many different stakeholders and contributed towards shifting farmers' perceptions of biodiversity from "an obligatory restriction, into an asset" (Fleury et al., 2015: 111). 


\section{Implications and Applications: Scaling Up}

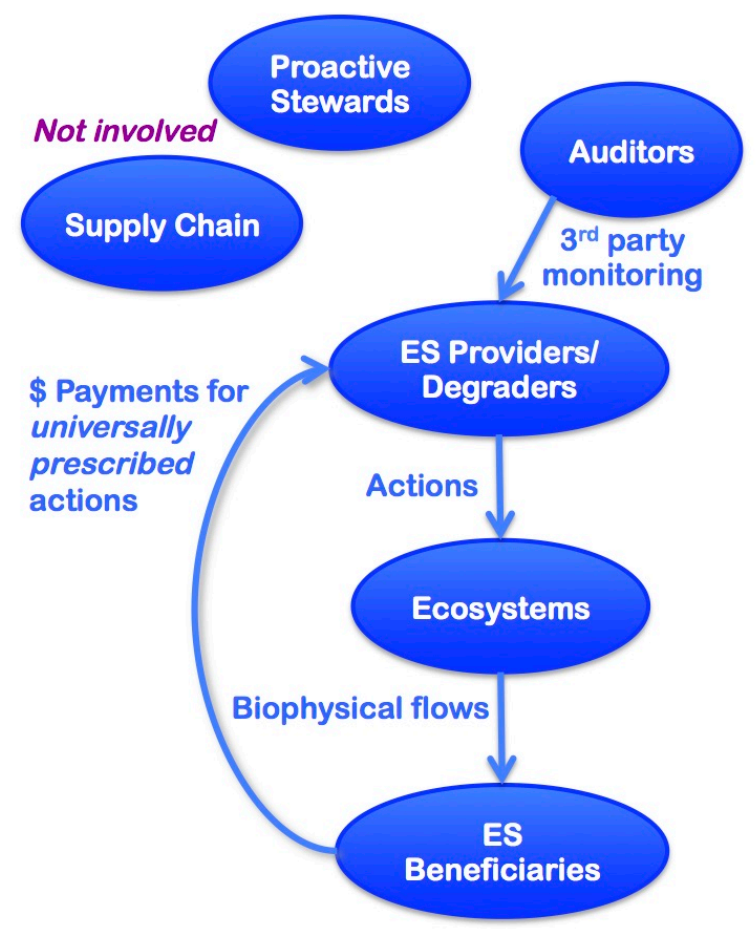

A. Narrow-Responsibility PES

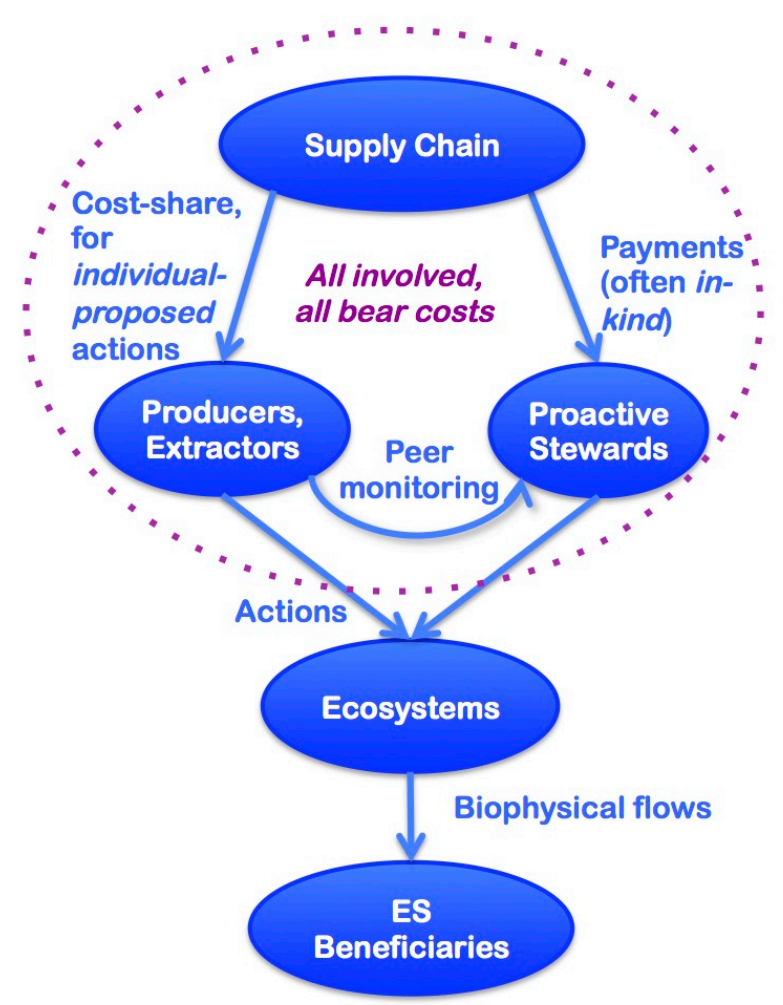

B. Responsibility-Extending PES

Figure 2. The current and proposed new models for payments for ecosystem services (PES), emphasizing design differences. (i) Whereas mainstream PES models (A) generally exclude the supply chain (including consumers, retailers, distributors, etc.), reimagined PES models (B) might include these firms and individuals as funders to share responsibilities broadly. (ii) Whereas mainstream models generally avoid paying stewards who are already undertaking positive actions (e.g., landowners who are already planting trees or maintaining set-asides), reimagined models would include such proactive agents-focusing on fairness, additionality of the whole program, and not sending signals that positive actions are worthless unless the landowners previously undertook negative actions. (iii) Whereas mainstream models favor cash payments, reimagined models favor in-kind payments and cost-share arrangements to crowd in inherent motivations (rather than crowding them out). (iv) Whereas mainstream models generally pay for universally prescribed actions, reimagined models would solicit proposals for individualized actions-enlisting agency in stewards and producers. (v) Whereas mainstream models generally require third-party monitoring (often at considerable cost), reimagined models might employ peer monitoring (with greatly reduced costs). Not all 
proposed changes will be feasible or appropriate everywhere.

Our analysis suggests that seven major shortcomings/limitations impede many PES programs from contributing substantially to sustainability, but that these problems are not insurmountable. Rather, several changes in program structure could have large effects in part via a conceptual shift from PES as tools for behaviour change given existing values and responsibilities (narrow-responsibility PES) to PES as tools for extending values and responsibilities (Figure 2). Here we focus on three broad shifts for such extension: crowding in (leveraging and increasing non-monetary motivations to participate), cultivating agency (fostering a self-organization in actions and monitoring), and embodying trust (spending funds on rewarding and encouraging stewardship rather than policing it). These three shifts permeate the seven solutions above.

By directly addressing the concerns and needs of ES providers, such programs have the potential to enhance stewardship values, thus promoting and fostering an ethic of more sustainable production (Anderson et al. in prep; Chapman et al., in prep; Olmsted et al., in prep). Such an ethic among engaged participants might also facilitate more efficient monitoring and evaluation by reducing the motivation to exploit shortcuts. Institutions articulate values, whether we like it or not, contributing to the formation of preferences and understandings of responsibilities (Vatn, 2005); perhaps it is time to recognize this explicitly, choosing and designing instruments not only for behaviour change but for the values they articulate. Large-scale PES and PES-like programs have been employed by governments in the EU, USA, Canada, China, Brazil, Central and South America, and beyond-all in pursuit of sustainable social-ecological relationships. By enlisting broader social-ecological literatures, we have proposed a suite of design shifts that might embody the conceptual shifts toward that worthy goal of sustainability. Several of the proposed design shifts have been implemented partially and separately, which attests to their feasibility, but new trials are needed to reveal the feasibility and effects of implementing them in context-dependent ways, intentionally, fully, and together.

For PES to contribute meaningfully to sustainability, they will require substantial involvement from firms - which may benefit from new or revised regulations. Presently, firms participate in PES primarily for corporate social responsibility or institutional investing (Dixon \& Challies, 2015), which are generally not seen as core business activities, although they may provide legitimacy to core activities. An estimated $58 \%$ of all forest carbon offsets in Asia are motivated by CSR-activities (Peters-Stanley et al., 2013), another form of philanthropy. The challenge from a firm perspective, then, is twofold: moving sustainability efforts from such peripheral activities into firms' core business models (Loorbach \& Rotmans, 2010, Geels, 2004), and ensuring that CSR moves beyond marketing to have meaningful impacts on the ground. Several government policy changes might foster this: e.g., governments may incentivize firms to be more active in the field by mandating innovative accounting standards (Engel, et al., 2008) defining more stringent CSR policies (Lyon \& Maxwell, 2008; Konar \& Cohen, 2001), and adopting new taxation tools (Kemkes, et al., 2010). Through the introduction of these and similar approaches, it is possible that firms' engaging in PES, in partnership with local communities, results in a sustainable image that is not merely a green sheen but a substantial contribution to innovation for sustainability.

From a research perspective, the challenge is to address incentive programs from a variety of disciplinary and interdisciplinary perspectives with long-term outcomes as a priority. It is not sufficient to claim, for example, that schemes paying for activities that would have occurred anyway likely suffer from low effectiveness. If the goal-as suggested in solution 4-is to normalize conservation (Chan et al., 2017 in press), such programs cannot be evaluated only at the scale of the individual landowner. If programs that resonate with local cultural ecosystem services and relational values could both foster 
community-scale stewardship norms (see above) and a sustained deep relationship with the land (Chan \& Satterfield 2016), individual additionality may be a myopic metric. A more integrated interdisciplinary perspective will be crucial to investigate the effectiveness of PES as both social and economic tools.

Ultimately, reimagined PES programs could contribute to the crucial task of normalizing the taking of responsibility for one's impacts-a potentially powerful relational value (Chan et al. 2016). Such a goal extends well beyond primary producers and governments, including private firms and individual consumers who are primary drivers of ecosystem impacts. In many sectors there is a clear willingness to support responsibly derived goods (Hollender \& Fenichell, 2004). Perhaps that latent willingness might be tapped much further, such that firms and consumers invest in PES not only to secure a sustainable supply of needed goods and services for their own benefit, but also to mitigate the impacts that accompany industrial production and consumption. As such, the PES that we imagine might enable not only ES providers, but also firms and consumers, to express moral values that are central to interpersonal ethics but are latent regarding environmentally mediated impacts. Many ethical approaches, including utilitarian and deontological, might recognize a responsibility to mitigate any impacts we have on others via our consumption and the environmental impacts entailed. And yet we are all complicit in environmental impacts via our purchases and lifestyles (albeit to highly variable degree, given concentrations of wealth and power), the vast majority of which go unmitigated. Our reimagined PES would therefore seek to provide an important new means for all consumers to express that core value in environmental settings.

This vision of shared-stewardship for collective impacts has inspired an incipient movement called CoSphere (a Community of Small-Planet Heroes, Ecologically Regenerating Economies, www.CoSphere.net). This new movement seeks large-scale market transformation by providing the missing infrastructure to enable individuals and firms to have net-positive impacts on our planet's biodiversity and ES, via contributions to conservation and stewardship in the form of PES programs designed as above. While we have great enthusiasm for CoSphere in particular, it represents but one possible manifestation of the transformative potential in reimagined PES.

\section{Acknowledgements}

The manuscript benefited from helpful comments from two anonymous reviewers. The authors would like to acknowledge the following funding sources: KMAC was supported by the Canada Research Chairs program and a Canadian Foundation for Innovation Leaders Opportunity Fund grant (UBC \# 17R39196); EA was supported by a Vanier Canada Graduate Scholarship, MC by a UBC Four-Year Fellowship, and PO by a NSERC Post-Graduate Scholarship (Doctoral). This research was also supported by a SSHRC Insight Grant (UBC \# 22R09598). 
Chan et al., Re-Imagining PES

\section{References}

Agrawal, A., Nepstad, D. \& Chhatre, A. (2011). Reducing emissions from deforestation and forest degradation. Annual Review of Environment and Resources, 36, 373-396. http://dx.doi.org/10.1146/annurev-environ-042009094508.

Ajayi, O. C., Jack, B. K., \& Leimona, B. (2012). Auction design for the private provision of public goods in developing countries: lessons from payments for environmental services in Malawi and Indonesia. World Development, 40(6), 1213-1223.

Anderson, E. K., \& Zerriffi, H. (2012). Seeing the trees for the carbon: Agroforestry for development and carbon mitigation. Climatic Change, 115(3): 741-757. http://dx.doi.org/10.1007/s10584-012-0456-y.

Ariely, D. (2008). Predictably Irrational: The Hidden Forces that Shape Our Decisions. New York: HarperCollins.

Arkema, K. K., Abramson, S. C., \& Dewsbury, B. M. (2006). Marine ecosystem-based management: From characterization to implementation. Frontiers in Ecology and the Environment, 4(10): 525-532.

http://dx.doi.org/10.1890/1540-9295(2006)4[525:MEMFCT]2.0.CO;2.

Bagri, A., Blockhus, J., \& Vorhies, F. (1999). Perverse subsidies and biodiversity loss. Draft scoping paper for IUCN, The World Conservation Union and the Van Lennep Programme, Gland, Switzerland. Retrieved from: http://www.biodiversityeconomics.org/pdf/topics-35-01. pdf.

Banerjee, A. V., Duflo, E., Glennerster, R. \& Kothari, D. (2010). Improving immunisation coverage in rural India: Clustered randomised controlled evaluation of immunisation campaigns with and without incentives. BMJ, 340. http://dx.doi.org/10.1136/bmj.c2220.

Barrett, C. B., Bulte, P., Ferraro, P. \& Wunder, S. (2013). Economic instruments for nature conservation. In D. W. Macdonald \& K. J. Willis (eds.), Key Topics in Conservation Biology 2 (pp 59-73). Oxford: Wiley-Blackwell.

Biggs, R., Schlüter, M., Biggs, D., Bohensky, E. L., Silver, S. B., Cundill, S., ... West, P. C. (2012). Toward principles for enhancing the resilience of ecosystem services. Annual Review of Environment and Resources, 37(1). http://www.annualreviews.org/doi/abs/10.1146/annurev-environ-051211-123836

Boyd, D. R. (2003). Unnatural Law: Rethinking Canadian Environmental Law and Policy. Vancouver: UBC Press. http://books.google.ca/books?id=SeYgVGE9j3EC

Bowles, S. (2008). Policies designed for self-interested citizens may undermine "the moral sentiments": Evidence from economic experiments. Science, 320(5883): 1605-1609.

http://dx.doi.org/10.1126/science.1152110.

Bremer, L. L. \& Farley, K. A. (2010). Does plantation forestry restore biodiversity or create green deserts? A synthesis of the effects of land-use transitions on plant species richness. Biodiversity and Conservation, 19(14): 3893-3915. http://dx.doi.org/10.1007/s10531-010-9936-4.

Brofeldt, S., Theilade, I., Burgess, N. D., Danielsen, F., Poulsen, M. K., Adrian, T., ... Widayati, A. (2014). Community monitoring of carbon stocks for REDD+: Does accuracy and cost change over time? Forests, 5(8): 1834-1854. http://dx.doi.org/10.3390/f5081834. 
Brooks, J. S., Waylen, K. A. \& Mulder, M. B. (2012). How national context, project design, and local community characteristics influence success in community-based conservation projects. Proceedings of the National Academy of Sciences of the United States of America, 109(52): 21265-21270.

http://dx.doi.org/10.1073\%2Fpnas.1207141110.

Brouwer, R., Tesfaye, A. \& Pauw, P. (2011). Meta-analysis of institutional-economic factors explaining the environmental performance of payments for watershed services. Environmental Conservation, 38(4): 380-392. http://dx.doi.org/10.1017/S0376892911000543.

Bryan, B. A., R. K. Runting, T. Capon, et al. (2016). Designer policy for carbon and biodiversity co-benefits under global change. Nature Clim. Change 6(3): 301-305. http://dx.doi.org/10.1038/nclimate2874

Burton, R. J. F. (2004). Seeing through the 'good farmer's' eyes: Towards developing an understanding of the social symbolic value of 'productivist' behaviour. Sociologia Ruralis, 44(2): 195-215.

http://dx.doi.org.10.1111/j.1467-9523.2004.00270.x.

Carlisle, L. (2013). Critical agrarianism. Renewable Agriculture and Food Systems, 29(02): 135-145. http://doi.org/10.1017/S1742170512000427.

Carlisle, L. (2015). Audits and agrarianism: The moral economy of an alternative food network. Elementa: Science of the Anthropocene, 3: 000066. http://doi.org/10.12952/journal.elementa.000066.

Chan, K. M. A., Gregr, E. J. \& Klain, S. (2009). A Critical Course Change. Science, 325(5946): 1342-1343.

Chan, K. M. A., Satterfield, T., \& Goldstein, J. (2012). Rethinking ecosystem services to better address and navigate cultural values. Ecological Economics, 74: 8-18.

Chan, K. M. A. and T. Satterfield (2016). Managing cultural ecosystem services for sustainability. Routledge Handbook of Ecosystem Services. M. Potschin, R. Haines-Young, R. Fish and R. K. Turner. London and New York, Routledge: 343-358.

Chan, K. M. A., Chapman, M., Chen, C., Enelow, N., Hesselgrave, T., \& Klain, S. C. (2015). The Values of Place: Recreation and Cultural Ecosystem Services in Puget Sound. (K. Biedenweg, Ed.) eopugetsound.org. Vancouver, BC.

Chan, K. M. A., Balvanera, P., Benessaiah, K., Chapman, M., Díaz, S., Gómez-Baggethun, E., ... Turner, N. (2016). "Why protect nature? Rethinking values and the environment." PNAS, 113(6): 1462-1465. http://www.pnas.org/content/113/6/1462.full

Chan, K. M. A., P. Olmsted, N. J. Bennett, S. C. Klain and E. Williams (2017 in press). Can ecosystem services make conservation normal and commonplace? Conservation for the Anthropocene Ocean: Interdisciplinary science in support of nature and people. P. S. Levin and M. R. Poe.

Chapman, M., K.M.A. Chan, T. Satterfield, H. Wittman (in prep). A payment by any other name: Market logic does not fully transfer from program managers to participants in Costa Rica's PES

Cheung, S. N. S. (1970). The structure of a contract and the theory of a non-exclusive resource. Journal of Law and Economics, 13(1): 49-70. http://www.sfu.ca/ wainwrig/Econ400/cheung-non-exclusive-resource.pdf.

Chopra, J., Adams, T., \& Zehnder, D. (2012). British Columbia Ecological Services Initiative. Journal of Ecosystems and Management, 12(3).

Cialdini, R. B. (2007). Descriptive social norms as underappreciated sources of social control. Psychometrika, 
72(2): 263-268. http://dx.doi.org/10.1007/s11336-006-1560-6.

Clot, S., G. Grolleau and P. Méral (2017). Payments vs. compensation for ecosystem services: Do words have a voice in the design of environmental conservation programs. Ecological Economics 135: 299-303.

http://www.sciencedirect.com/science/article/pii/S0921800916303056

Coase, R. H. (1960). The problem of social cost. Journal of Law and Economics, 3: 1-44. Retrieved from: http://www.jstor.org/stable/724810.

Cooper, J. (2007). Cognitive Dissonance: Fifty Years of a Classical Theory. London: Sage Publications.

Corbera, E., C. G. Soberanis and K. Brown (2009). "Institutional dimensions of Payments for Ecosystem Services: An analysis of Mexico's carbon forestry programme." Ecological Economics 68(3): 743-761. http://www.sciencedirect.com/science/article/pii/S0921800908002632

Corbera, E. \& Schroeder, H. (2011). Governing and implementing REDD+. Environmental Science \& Policy, 14(2), 89-99. http://dx.doi.org/10.1016/j.envsci.2010.11.002.

Daily, G. C. \& Ellison, K. (2002). The New Economy of Nature: The Quest to Make Conservation Profitable. Washington, DC: Island Press.

Daniels, A. E., Bagsted, K., Esposito, V., Moulaert, A. \& Rodriguez, C. M. (2010). Understanding the impacts of Costa Rica's PES: Are we asking the right questions? Ecological Economics, 69(11): 2116-2126.

http://dx.doi.org/10.1016/j.ecolecon.2010.06.011.

Danielsen, F., Adrian, T., Brofeldt, S., van Noordwijk, M., Poulsen, M. K., Rahayu, S., ... Burgess, N. (2013). Community monitoring for REDD+: International promises and field realities. Ecology and Society, 18(3): 41. http://dx. doi.org/10.5751/ES-05464-180341.

Danielsen, F., Jensen, A. E., Alviola, P. A., Balete, D. S., Mendoza, M., Tagtag, A., ... Enghoff, M. (2005). Does monitoring matter? A quantitative assessment of management decisions from locally-based monitoring of protected areas. Biodiversity and Conservation, 14(11): 2633-2652. http://dx.doi.org/10.1007/s10531-005-8392$\mathrm{z}$.

Dauvergne, P. and J. Lister (2012). Big brand sustainability: Governance prospects and environmental limits. Global Environmental Change, 22(1): 36-45.

http://www.sciencedirect.com/science/article/pii/S0959378011001609

De Martino, S., F. Kondylis and A. Zwager (2017). Protecting the environment for love or money? The role of motivation and incentives in shaping demand for payments for environmental services programs. Public Finance Review 45(1): 68-96. http://journals.sagepub.com/doi/abs/10.1177/1091142115604352

de Oliveira, D., \& Rebelatto dos Santos, L. C. (2005). Caderno de Formação (pp. 1-48).

Díaz, S., Demissew, S., Carabias, J., Joly, C., Lonsdale, M., Ash, N., ... Pascual, U. (2015). The IPBES conceptual framework - Connecting nature and people. Current Opinion in Environmental Sustainability, 14: 116. http://doi.org/10.1016/j.cosust.2014.11.002.

Dixit, A. \& Olson, M. (2000). Does voluntary participation undermine the Coase theorem? Journal of Public Economics, 76: 309-335.

Dixon, R. \& Challies, E. (2015). Making REDD+ pay: Shifting rationales and tactics of private finance and the governance of avoided deforestation in Indonesia. Asia Pacific Viewpoint, 56(1): 6-20. 
http://dx.doi.org/10.1111/apv.12085.

Dougill, A. J., Stringer, L. C., Leventon, J., Riddell, M., Rueff, H., Spracklen, D. V. \& Butt, E. (2012). Lessons from community-based payment for ecosystem service schemes: From forests to rangelands. Philosophical Transactions of the Royal Society of London B: Biological Sciences, 367(1606). http://dx.doi.org/10.1098/rstb.2011.0418.

Duinker, P. N. \& Greig, L. A. (2006). The impotence of cumulative effects assessment in Canada: Ailments and ideas for redeployment. Environmental Management 37(2): 153-161. http://dx.doi.org/10.1007/s00267-0040240-5.

The Economist (2005). Are you being served? The Economist, 2005: 76-78.

Engel, S., Pagiola, S. \& Wunder, S. (2008). Designing payments for environmental services in theory and practice: An overview of the issues. Ecological Economics, 65(4): 663-674. http://dx.doi.org/10.1016/j.ecolecon.2008.03.011.

Engel, S. (2016). The devil in the detail: A practical guide on designing payments for environmental services. International Review of Environmental and Resource Economics 9(1-2): 131-177. http://dx.doi.org/10.1561/101.00000076

Farley, K. A., Jobbágy, E. G. \& Jackson, R. B. (2005). Effects of afforestation on water yield: A global synthesis with implications for policy. Global Change Biology 11(10): 1565-1576. http://dx.doi.org/10.1111/j.13652486.2005.01011.x

Fehr, E. \& Falk, A. (2002). Psychological foundations of incentives. European Economic Review, 46(4-5): $687-$ 724. http://dx.doi.org/10.1016/S0014-2921(01)00208-2.

Fehr, E. \& Gächter, S. (2001). Do incentive contracts crowd out voluntary cooperation? CEPR Discussion Paper No. 3017. Retrieved from: www.cepr.org/pubs/dps/DP3017.asp.

Ferraro, P. J. \& Kiss, A. (2002). Direct payments to conserve biodiversity. Science, 298(5599): 1718-1719. http://dx.doi.org/10.1126/science.1078104.

Festinger, L. (1962). Cognitive dissonance. Scientific American, 207(4): 93-107. http://dx.doi.org/10.1038/scientificamerican1062-93.

Fleury, P., Seres, C., Dobremez, L., Nettier, B. \& Pauthenet, Y. (2015). “Flowering meadows," a result-oriented agri-environmental measure: Technical and value changes in favour of biodiversity. Land Use Policy, 46: 103114. http://doi.org/10.1016/j.landusepol.2015.02.007.

Flores, K. R., Silva, F. \& Volkmann, P. (2009). Shall we still keep our eyes cerrados? In S. Böhm \& S. Dabhi (eds.) Upsetting the Offset: The Political Economy of Carbon Markets (pp. 112-118). London: MayFlyBooks.

Frey, B. S. \& Oberholzer-Gee, F. (1997). The cost of price incentives: An empirical analysis of motivation crowding-out. The American Economic Review, 87(4): 746-755. Retrieved from http://www.jstor.org/stable/2951373.

Gallemore, C. \& Munroe, D. K. (2013). Centralization in the global avoided deforestation collaboration network. Global Environmental Change, 23(5): 1199-1210. http://dx.doi.org/10.1016/j.gloenvcha.2013.04.004.

Geels, F. W. (2004). From sectoral systems of innovation to socio-technical systems: Insights about dynamics and change from sociology and institutional theory. Research Policy, 33(6-7), 897-920. 
http://dx.doi.org/10.1016/j.respol.2004.01.015.

Gneezy, U. and A. Rustichini (2000). "A fine is a price." The Journal of Legal Studies 29(1): 1-17.

http://www.journals.uchicago.edu/doi/abs/10.1086/468061

Goldman, R. L., Tallis, H., Kareiva, P. \& Daily, G. C. (2008). Field evidence that ecosystem service projects support biodiversity and diversify options. Proceedings of the National Academy of Sciences of the United States of America, 105(27): 9445-9448. http://dx.doi.org/10.1073/pnas.0800208105.

Goldman-Benner, R. L., S. Benitez, T. Boucher, A. Calvache, G. Daily, P. Kareiva, T. Kroeger and A. Ramos (2012). "Water funds and payments for ecosystem services: practice learns from theory and theory can learn from practice." Oryx 46(01): 55-63. http://dx.doi.org/10.1017/S0030605311001050

Goldstein, J. (2005). Betting on markets: Australia's five-million dollar experiment with market-based instruments. Ecosystem Marketplace.

Gómez-Baggethun, E. \& Muradian, R. (2015). In markets we trust? Setting the boundaries of market-based instruments in ecosystem service governance. Ecological Economics, 117: 217-224. http://dx.doi.org/ 10.1016/j.ecolecon.2015.03.016.

Gómez-Baggethun, E. \& Ruiz-Pérez, M. (2011). Economic valuation and the commodification of ecosystem services. Progress in Physical Geography, 35(5): 613-628.

http://dx.doi.org/10.1177/0309133311421708.

Grumbine, R. E. (1997). Reflections on "what is ecosystem management?" Conservation Biology, 11(1): 41-47. http://dx.doi.org/10.1046/j.1523-1739.1997.95479.x.

Hajjar, R. (2014). Advancing small-scale forestry under FLEGT and REDD in Ghana. Forest Policy and Economics, 58: 12-20. http://dx.doi.org/10.1016/j.forpol.2014.09.014.

Hanley, N., Shogren, J. \& White, B. (2001). Introduction to Environmental Economics. Oxford: Oxford University Press.

Harris, J. M. (2002). Environmental and Natural Resource Economics: A Contemporary Approach. Boston: Houghton Mifflin.

Heath, C. \& Heath, D. (2010). Switch: How to change things when change is hard. New York: Crown Publishing Group. http://books.google.ca/books?id=QgzBqhbdlvUC

Helm, D. (2015). Natural Capital: Valuing the Planet. Yale: Yale University Press.

https://books.google.ca/books?id=zjDCCAAAQBAJ

Heyman, J. \& Ariely, D. (2004). Effort for payment: A tale of two markets. Psychological Science, 15(11): 787793. http://dx.doi.org/10.1111/j.0956-7976.2004.00757.x.

Hollender, J. \& Fenichell, S. (2004). What Matters Most: How a Small Group of Pioneers Is Teaching Social Responsibility to Big Business, and Why Big Business Is Listening. USA: Basic Books.

Igoe, J. (2013). Consume, connect, conserve: Consumer spectacle and the technical mediation of neoliberal conservation's aesthetic of redemption and repair. Human Geography, 6(1). 16-28.

Jack, B. K., C. Kousky and K. R. E. Sims (2008). Designing payments for ecosystem services: Lessons from previous experience with incentive-based mechanisms. Proceedings of the National Academy of Sciences of the 
Jack, B. K., Leimona, B. \& Ferraro, P. J. (2009). A revealed preference approach to estimating supply curves for ecosystem services: Use of auctions to set payments for soil erosion control in Indonesia. Conservation Biology, 23(2): 359-367. http://dx.doi.org/ 10.1111/j.1523-1739.2008.01086.x.

Jackson, R. B., Jobbagy, E. G., Avissar, R., Roy, S. B., Barrett, D. J., Cook, C. W. ... Murray, B. C. (2005). Trading water for carbon with biological sequestration. Science, 310(5756): 1944-1947.

http://dx.doi.org/10.1126/science.1119282

Jindal, R., Swallow, B. \& Kerr, J. (2008). Forestry-based carbon sequestration projects in Africa: Potential benefits and challenges. Natural Resources Forum, 32(2): 116-130. http://dx.doi.org/10.1111/j.14778947.2008.00176.x

Kaczan, D., B. M. Swallow and W. L. Adamowicz (2013). Designing a payments for ecosystem services (PES) program to reduce deforestation in Tanzania: An assessment of payment approaches. Ecological Economics 95: 20-30. http://www.sciencedirect.com/science/article/pii/S0921800913002516

Kaplan, S. (2000). New ways to promote proenvironmental behaviour: Human nature and environmentally responsible behavior. Journal of Social Issues, 56(3): 491-508. http://dx.doi.org/10.1111/0022-4537.00180.

Kemkes, R. J., Farley, J. \& Koliba, C. J. (2010). Determining when payments are an effective policy approach to ecosystem service provision. Ecological Economics, 69(11): 2069-2074.

http://dx.doi.org/10.1016/j.ecolecon.2009.11.032.

Kerr, J., M. Vardhan and R. Jindal (2012). Prosocial behavior and incentives: Evidence from field experiments in rural Mexico and Tanzania. Ecological Economics 73: 220-227.

http://www.sciencedirect.com/science/article/pii/S0921800911004605

Kinzig, A. P., Perrings, C., Chapin, F. S., Polasky, S., Smith, V. K., Tilman, D. \& Turner, B. L. (2011). Paying for ecosystem services - Promise and peril. Science, 334(6056): 603-604.

http://dx.doi.org/10.1126/science.1210297.

Kits, G. J., Adamowicz, W. \& Boxall, P. C. (2014). Do conservation auctions crowd out voluntary environmentally friendly activities? Ecological Economics, 105: 118-123. http://dx.doi.org/10.1016/j.ecolecon.2014.05.014.

Kolinjivadi, V., A. Grant, J. Adamowski and N. Kosoy (2015). Juggling multiple dimensions in a complex socioecosystem: The issue of targeting in payments for ecosystem services. Geoforum 58: 1-13.

http://www.sciencedirect.com/science/article/pii/S0016718514002206

Konar, S., \& Cohen, M. A. (2001). Does the market value environmental performance? Review of Economics and Statistics, 83(2), 281-289.

Kosoy, N., Martinez-Tuna, M., Muradian, R. \& Martinez-Alier, J. (2007). Payments for environmental services in watersheds: Insights from a comparative study of three cases in Central America. Ecological Economics, 61: 446-455. http://dx.doi.org/10.1016/j.ecolecon.2006.03.016.

Kosoy, N. \& Corbera, E. (2010). Payments for ecosystem services as commodity fetishism. Ecological Economics, 69: 1228-1236. http;//dx.doi.org/10.1016/j.ecolecon.2009.11.002.

Lapeyre, R., R. Pirard and B. Leimona (2015). Payments for environmental services in Indonesia: What if economic signals were lost in translation? Land Use Policy 46: 283-291.

http://www.sciencedirect.com/science/article/pii/S0264837715000769 
Chan et al., Re-Imagining PES

Larrazábal, A., McCall, M. K., Mwampamba, T. H. \& Skutsch, M. (2012). The role of community carbon monitoring for REDD+: A review of experiences. Current Opinion in Environmental Sustainability, 4(6): 707-716. http://dx.doi.org/10.1016/j.cosust.2012.10.008.

Leimona, B., B. Lusiana, M. van Noordwijk, E. Mulyoutami, A. Ekadinata and S. Amaruzaman (2015). Boundary work: Knowledge co-production for negotiating payment for watershed services in Indonesia. Ecosystem Services 15: 45-62. http://www.sciencedirect.com/science/article/pii/S2212041615300139

Levy, D. L. \& Newell, P. J. (2005). The Business of Global Environmental Governance. Cambridge, MA, USA: MIT press.

Levin, S. A. (1992). The problem of pattern and scale in ecology: The Robert H. MacArthur Award lecture. Ecology, 73(6): 1943-1967. http://dx.doi.org/10.2307/1941447.

Lockie, S. (2013). Market instruments, ecosystem services, and property rights: Assumptions and conditions for sustained social and ecological benefits. Land Use Policy 31: 90-98.

http://www.sciencedirect.com/science/article/pii/S0264837711001232

Loorbach, D., \& Rotmans, J. (2010). The practice of transition management: Examples and lessons from four distinct cases. Futures, 42(3), 237-246. http://dx.doi.org/10.1016/j.futures.2009.11.009.

Luck, G. W., Chan, K. M. A., Eser, U., Gómez-Baggethun, E., Matzdorf, B., Norton, B. \& Potschin, M. B. (2012). Ethical considerations in on-ground applications of the ecosystem services concept. BioScience, 62(12): 10201029. http;//dx.doi.org/10.1525/bio.2012.62.12.4.

Lyon, T. P., \& Maxwell, J. W. (2008). Corporate social responsibility and the environment: A theoretical perspective. Review of Environmental Economics and Policy, 2(2), 240-260.

Matthews, R. B., van Noordwijk, M., Lambin, E., Meyfroidt, P., Gupta, J., Verchot, L., ... Veldkamp, E. (2014). Implementing REDD+ (Reducing Emissions from Deforestation and Degradation): Evidence on governance, evaluation and impacts from the REDD-ALERT project. Mitigation and Adaptation Strategies for Global Change, 19: 907-925. http://dx.doi.org/10.1007/s11027-014-9578-z.

Mauerhofer, V., Hubacek, K., \& Coleby, A. (2013). From polluter pays to provider gets: Distribution of rights and costs under payments for ecosystem services. Ecology and Society, 18(4): 41.

McAfee, K. \& Shapiro, E. N. (2010). Payments for ecosystem services in Mexico: Nature, neoliberalism, social movements, and the state. Annals of the Association of American Geographers, 100(3): 579-599.

http;//dx.doi.org/10.1080/00045601003794833.

McLeod, K. \& Leslie, H. (eds.) (2009). Ecosystem Based Management for the Oceans. Washington, DC: Island Press.

Meadows, D. H. (2009). Thinking in Systems: A Primer. London: Earthscan.

Millennium Ecosystem Assessment (2005). Ecosystems and Human Well-being: Synthesis. Washington, DC: Island Press.

Moeliono, M., Gallemore, C., Santoso, L., Brockhaus, M. \& Di Gregorio, M. (2014). Information networks and power: Confronting the 'wicked problem' of REDD+ in Indonesia. Ecology and Society, 19(2): 9.

http://dx.doi.org/10.5751/ES-06300-190209.

Muradian, R., Corbera, E., Pascual, U., Kosoy, N. \& May, P. H. (2010). Reconciling theory and practice: An 
Chan et al., Re-Imagining PES

alternative conceptual framework for understanding payments for environmental services. Ecological Economics, 69: 1202-1208. http;//dx.doi.org/10.1016/j.ecolecon.2009.11.006.

Muradian, R., M. Arsel, L. Pellegrini, et al. (2013). "Payments for ecosystem services and the fatal attraction of win-win solutions." Conservation Letters 6(4): 274-279. http://dx.doi.org/10.1111/j.1755-263X.2012.00309.x

Naeem, S., Ingram, J. C., Varga, A., Agardy, T., Barten, P., Bennett, G., ... Wunder, S. (2015). Get the science right when paying for nature's services. Science, 347(6227): 1206-1207.

http;//dx.doi.org/10.1126/science.aaa1403.

Narloch, U., Pascual, U. \& Drucker, A. G. (2011). Cost-effectiveness targeting under multiple conservation goals and equity considerations in the Andes. Environmental Conservation, 38(4): 417-425.

http://dx.doi.org/10.1017/S0376892911000397.

Newton, A. C. (2011). Implications of Goodhart's Law for monitoring global biodiversity loss. Conservation Letters, 4(4): 264-268. http;//dx.doi.org/10.1111/j.1755-263X.2011.00167.x.

Norgaard, R. B. (2010). Ecosystem services: From eye-opening metaphor to complexity blinder. Ecological Economics, 69: 1219-1227. http;//dx.doi.org/10.1016/j.ecolecon.2009.11.009.

Oreskes, N. (2004). Science and public policy: What's proof got to do with it? Environmental Science and Policy, 7: 369-383. http;//dx.doi.org/10.1016/j.envsci.2004.06.002.

Pagiola, S. (2008). Payments for environmental services in Costa Rica. Ecological Economics, 65: 712-724. http://dx.doi.org/10.1016/j.ecolecon.2007.07.033.

Pallak, M. S., Cook, D. A. \& Sullivan, J. J. (1980). Commitment and energy conservation. Policy Studies Review Annual, 4: 352.

Pascual, U., Muradian, R., Rodríguez, L. C. \& Duraiappah, A. (2010). Exploring the link between equity and efficiency in payments for environmental services: A conceptual approach. Ecological Economics, 69: 12371244. http://dx.doi.org/10.1016/j.ecolecon.2009.11.004.

Pascual, U., Phelps, J., Garmendia, E., Brown, K., Corbera, E., Martin, A., ... Muradian, R. (2014). Social equity matters in payments for ecosystem services. BioScience, 64(11): 1027-1036.

Perman, R., Ma, Y., Common, M. \& McGilvray, J. (2003). Natural Resource and Environmental Economics (3rd ed.). Harlow: Addison Wesley.

Perrot-Maitre, D. (2006). The Vittel Payments for Ecosystem Services: A "Perfect" PES Case? London: International Institute for Environment and Development.

Peters-Stanley, M., Gonzalez, G., Yin, D., Goldstein, A. \& Hamrick, K. (2013). Covering new ground: State of the forest carbon markets 2013. Forest Trends' Ecosystem Marketplace.

Polasky, S. (1997). Biodiversity loss: Economic and ecological issues. Journal of Economic Literature, 35(2): 823-824.

Porras, I., Barton, D. N., Miranda M. \& Chacón-Cascante, A. (2013). Learning from 20 Years of Ecosystem Services in Costa Rica. London: International Institute for Environment and Development.

Prager, C. M., Varga, A., Olmsted, P., Ingram, J. C., Cattau, M., Freund, C., ... Naeem, S. (2015). An assessment of adherence to basic ecological principles by payments for ecosystem service projects. 
Conservation Biology, O(0): 1-10. http://dx.doi.org/10.1111/cobi.12648.

Pratihast, A. K., Herold, M., De Sy, V., Murdiyarso, D. \& Skutsch, M. (2013). Linking community-based and national REDD+ monitoring: A review of the potential. Carbon Management, 4(1): 91-104.

http://dx.doi.org/10.4155/cmt.12.75.

Prokofieva, I., Wunder, S., \& Vidale, E. (2012). Payments for environmental services: a way forward for Mediterranean forests? EFI Policy Brief, (7).

Prudham, S. (2007). The fictions of autonomous invention: Accumulation by dispossession, commodification and life patents in Canada. Antipode, 39(3): 406-429. http://dx.doi.org/10.1111/j.1467-8330.2007.00533.x.

Redford, K. H., \& Adams, W. M. (2009). Payment for ecosystem services and the challenge of saving nature. Conservation Biology, 23(4): 785-787. http://doi.org/10.1111/j.1523-1739.2009.01271.x.

Reeson, A. F. \& Tisdell, J. G. (2008). Institutions, motivations and public goods: An experimental test of motivational crowding out. Journal of Economic Behaviour \& Organization, 68(1): 273-281.

http://doi.org/10.1016/j.jebo.2008.04.002.

Rendón-Thompson, O. R., Paavola, J., Healey, J. R., Jones, J. P. G., Baker, T. R., \& Torres, J. (2013). Reducing Emissions from Deforestation and Forest Degradation (REDD+): Transaction costs of six Peruvian projects. Ecology and Society, 18(1): 17. http://dx.doi.org/10.5751/ES-05239-180117.

Rode, J., Goméz-Baggethun, E. \& Krause, T. (2015). Motivation crowding by economic incentives in conservation policy: A review of the empirical evidence. Ecological Economics, 117: 270-282.

doi:10.1016/j.ecolecon.2014.11.019.

Rode, J., Wittmer, H., Emerton, L. \& Schröter-Schlaack, C. (2016). 'Ecosystem service opportunities': A practiceoriented framework for identifying economic instruments to enhance biodiversity and human livelihoods. Journal for Nature Conservation 33: 35-47. http://www.sciencedirect.com/science/article/pii/S161713811630053X

Rover, O. (2011). Agroecologia, mercado e inovação social: o caso da Rede Ecovida de Agroecologia. Ciências Sociais Unisinos, 47(1), 56-63.http://doi.org/10.4013/csu.2011.47.1.06

Russell, C. S. (2001). Applying Economics to the Environment. Oxford: Oxford University Press.

Samii, C., M. Lisiecki, P. Kulkarni, L. Paler \& L. Chavis (2014). Effects of payment for environmental services (PES) on deforestation and poverty in low and middle income countries: a systematic review. Campbell Systematic Reviews, 10(11).

Shore, C., \& Wright, S. (2015). Audit culture revisited. Current Anthropology, 56(3): 421-444. http://doi.org/10.1086/681534.

Singh, G., J. Lerner, M. Mach, C. Clarke Murray, B. Ranieri, G. Peterson St-Laurent, J. Wong, A. Guimaraes, G. Yunda-Guarin, T. Satterfield, K.M.A. Chan. (submitted). "Global scientific shortcomings in Environmental Impact Assessment."

Smith, K. K. (2003). Wendell Berry and the Agrarian Tradition. Lawrence: University Press of Kansas.

Solazzo, A., Jones, A., \& Cooper, N. (2015). Revising payment for ecosystem services in the light of stewardship: The need for a legal framework. Sustainability, 7(11): 15449-15463.

Sommerville, M. M., Jones, J. P. G. \& Milner-Gulland, E. J. (2009). A revised conceptual framework for 
payments for environmental services. Ecology and Society, 14(2): 34.

Spash, C. L. (2008). How much is that ecosystem in the window? The one with the bio-diverse trail. Environmental Values, 259-284.

Stoneham, G., Chaudhri, V., Ha, A. \& Strappazzon, L. (2003). Auctions for conservation contracts: An empirical examination of Victoria's BushTender trial. The Australian Journal of Agricultural and Resource Economics, 47: 477-500. Retrieved from: http://digitalcollections.anu.edu.au/handle/1885/40973.

Swallow, B. M., M. F. Kallesoe, U. A. Iftikhar, et al. (2009). Compensation and rewards for environmental services in the developing world: framing pan-tropical analysis and comparison. Ecology and Society 14(2): 26. http://www.ecologyandsociety.org/vol14/iss2/art26/

Tietenberg, T. H. (2003). Environmental and Natural Resource Economics (6th ed.). Boston: Addison Wesley.

Van Hecken, G. \& Bastiansen, J., (2010). Payments for ecosystem services in Nicaragua: Do market-based approaches work? Development and Change, 41(3): 421-444. http://dx.doi.org/10.1111/j.14677660.2010.01644.x.

Van Noordwijk, M. \& Leimona, B. (2010). Principles for fairness and efficiency in enhancing environmental services in Asia: Payments, compensation, or co-investment. Ecology and Society 15(4): Article 17. Retrieved from: http://www.ecologyandsociety.org/vol15/iss4/art17/.

Van Noordwijk, M., Leimona, B., Jindal, R., Villamor, G. B., Vardhan, M., Namirembe, S., ... Tomich, T. P. (2012). Payments for environmental services: Evolution toward efficient and fair incentives for multifunctional landscapes. Annual Review of Environment and Resources, 37(1): 389-420. http;//dx.doi.org/10.1146/annurevenviron-042511-150526.

Van Noordwijk, M., Matthews, R., Agus, F., Farmer, J., Verchot, L., Hergoualc'h, K., ... Dewi, S. (2014). Mud, muddle and models in the knowledge value-chain to action on tropical peatland conversion. Mitigation and Adaptation Strategies for Global Change, 19(6): 887-905. http://dx.doi.org/10.1007/s11027-014-9576-1.

Vatn, A. (2005). "Rationality, institutions and environmental policy." Ecological Economics 55(2): 203-217. http://www.sciencedirect.com/science/article/pii/S0921800904004112

Vatn, A. (2010). An institutional analysis of payments for environmental services. Ecological Economics, 69: 1245-1252. http://dx.doi.org/10.1016/j.ecolecon.2009.11.018.

Vickrey, W. (1961). Counterspeculation, auctions, and competitive sealed tenders. The Journal of Finance, 16(1), 8-37.

Vignola, R., McDaniels, T. L. \& Scholz, R. W. (2012). Negotiation analysis for mechanisms to deliver ecosystem services: The case of soil conservation in Costa Rica. Ecological Economics, 75: 22-31. http://dx.doi.org/10.1016/j.ecolecon.2012.01.004.

World Resources Institute (WRI), World Business Council on Sustainable Development (WBCSD) and Meridian Institute (2008). The Corporate Ecosystem Services Review: Guidelines for Identifying Business Risks and Opportunities Arising from Ecosystem Change. WBCSD Publications: 37+vi. http://www.wbcsd.org/Plugins/DocSearch/details.asp?DocTypeld=25\&Objectld=Mjg5NjQ

Wilcove, D. S. (1998). The promise and disappointment of the Endangered Species Act. New York University Environmental Law Journal, 6: 275-278. 
Wilcove, D. S. \& Lee, J. (2004). Using economic and regulatory incentives to restore endangered species: Lessons learned from three new programs. Conservation Biology, 18(3): 639-645.

http://dx.doi.org/10.1111/j.1523-1739.2004.00250.x.

Wittman, H. K., \& Caron, C. (2009). Carbon offsets and inequality: Social costs and co-benefits in Guatemala and Sri Lanka. Society \& Natural Resources, 22(8): 710-726. http://doi.org/10.1080/08941920802046858.

Wittman, H., Powell, L. J. \& Corbera, E. (2015). Financing the agrarian transition? The Clean Development Mechanism and agricultural change in Latin America. Environment and Planning, 47: 2031-2046. http://dx.doi.org/ 10.1068/a130218p.

Wunder, S. (2005). Payments for environmental services: Some nuts and bolts. CIFOR Occasional Paper No. 42. http://dx.doi.org/10.17528/cifor/001760.

Wunder, S. (2013). When payments for environmental services will work for conservation. Conservation Letters, 6(4): 230-237. http://dx.doi.org.10.1111/conl.12034.

Wunder, S., Engel, S. \& Pagiola, S. (2008). Taking stock: A comparative analysis of payments for environmental services programs in developed and developing countries. Ecological Economics, 65(4): 834-852. http://dx.doi.org/10.1016/j.ecolecon.2008.03.010.

Wynne-Jones, S. (2012). Negotiating neoliberalism: Conservationists' role in the development of payments for ecosystem services. Geoforum, 43(6): 1035-1044. http://doi.org/10.1016/j.geoforum.2012.07.008.

Zammit, C. (2013). Landowners and conservation markets: Social benefits from two Australian government programs. Land Use Policy, 31: 11-16. http://dx.doi.org/10.1016/j.landusepol.2012.01.011. 